papier aangeven dat er sprake is van een toegenomen zelfredzaamheid, dat immers zoveel verschillende betekenissen heeft.

\section{Kwetsend}

Dat geeft professionals veel ruimte. Mooi, want dat is ook een van de doelen van het huidige beleid. Toch is het problematisch dat zo'n inhoudsloos opgerekt begrip zo leidend kan zijn. Want hierdoor kan het beleid niet door de praktijk worden gecorrigeerd. Straks 'blijkt' uit nog veel meer evaluaties dat de zelfredzaamheid van Nederlanders sinds de decentralisaties sterk is toegenomen. De regering kan er mooie sier mee maken en betogen dat mensen elkaar dus veel meer kunnen helpen dan gedacht. Ze kan er ook verdere bezuinigingen mee legitimeren. Waardoor professionals nog harder moeten rennen om mensen toch te kunnen helpen.

Bovendien kunnen hoge verwachtingen van het netwerk schade aanrichten. Want wijkteamleden moeten doorvragen: 'Kan je zoon of dochter niet wat vaker komen? Kun je de buren niet vragen?' En, als mensen niet meteen iemand weten die kan helpen: 'Wie was er op je laatste verjaardag? Met welke ouders praat je wel eens op het schoolplein?' Daarmee belasten ze mensen met schuld- en schaamtegevoelens. Een eenzame alleenstaande moeder werd bijvoorbeeld gedwongen ouders van een vriendje om hulp te vragen. Die ouders kende ze nauwelijks en het was ook niet verwonderlijk, maar wel beschamend en kwetsend dat deze mensen afwijzend reageerden.

De nabijheid van de keukentafel is een grote verworvenheid. Maar gemeenten doen er goed aan professionals met een breder ideaal op pad te sturen. Niet zelfredzaamheid, maar kwaliteit van leven zou centraal moeten staan. Zelf doen en het netwerk aanspreken kan daarbij behulpzaam zijn, maar kan evengoed schaden. Hoe kan uw levenskwaliteit verbeteren, en wat kunnen naasten en sociale voorzieningen daaraan bijdragen? Dat zou de centrale vraag moeten zijn waar gemeenten professionals mee op pad sturen.

\title{
Gemeenten en thuiszorgmedewerkers zouden meer oog moeten hebben voor mantelzorgers
}

\author{
Mirjam de Klerk · Alice de Boer · Inger Plaisier
}

Published online: 5 November 2018

(C) Bohn Stafleu van Loghum is een imprint van Springer Media B.V., onderdeel van Springer Nature 2018

\begin{abstract}
Mensen die zorg en ondersteuning krijgen, ontvangen die meestal van mensen uit hun eigen sociale netwerk. Ongeveer een derde van de Nederlanders geeft mantelzorg. Welke ervaringen hebben zij met de Wmo? Er zijn indicaties dat de gemeenten en zorgmedewerkers nog onvoldoende oog voor hen hebben.
\end{abstract}

\footnotetext{
M. de Klerk $(\bowtie) \cdot$ A. de Boer · I. Plaisier

Sociaal en Cultureel Planbureau, Den Haag, Nederland

m.de.klerk@scp.nl

A. de Boer

Vrije Universiteit Amsterdam, Amsterdam, Nederland
}

\section{Welke taken hebben gemeenten als het gaat om mantelzorg?}

Uitgangspunt van het beleid is dat mensen meer voor elkaar zouden kunnen zorgen en dat iemand die ondersteuning nodig heeft eerst in eigen kring nagaat of hij die daar kan krijgen. Gemeenten dienen ook te voorkomen dat mantelzorgers overbelast worden door hen zo nodig mantelzorgondersteuning te bieden. Dat kan bijvoorbeeld door mantelzorgers te betrekken bij het onderzoek naar de hulpvraag van de cliënt of door zorgmedewerkers aan te moedigen om niet alleen naar de cliënt te kijken, maar ook naar zijn of haar naasten. Dit klinkt mooi, maar de praktijk is weerbarstig. 


\section{Doen gemeenten een beroep op mantelzorg?}

Tussen 2014 en 2016 is het aandeel Nederlanders dat mantelzorg geeft aan iemand met gezondheidsbeperkingen niet veranderd, zo blijkt uit onderzoek van het SCP: in beide jaren geeft circa een derde van de volwassen bevolking hulp aan familie, vrienden of buren. Ook het aantal uren bleef gelijk. Het lijkt erop dat gemeenten er niet in slagen een groter beroep te doen op mantelzorgers [1]. Onderzoek van Bredewold en anderen bevestigt dat beeld: zij schatten in dat in ongeveer $90 \%$ van de door hen onderzochte keukentafelgesprekken geen (groter) beroep op het sociale netwerk wordt gedaan. Zij wijten dat onder meer aan het feit dat het netwerk al veel doet of dat er lang niet altijd een netwerk is [2]. Ook een gebrek aan tijd, een slechte gezondheid of een slechte relatie met de hulpbehoevende kunnen redenen zijn om geen mantelzorg te geven. Een op de vier mantelzorgers geeft aan indien nodig (beslist) niet nog meer te kunnen doen [1]. Met andere woorden: er lijkt weinig rek te bestaan bij mantelzorgers.

\section{Hebben gemeenten oog voor mantelzorgers?}

Mantelzorgers kunnen overbelast raken en uitvallen als zij worden overvraagd. Dat betekent dat gemeenten goed op hun mantelzorgers moeten letten. Doen zij dat ook? De mantelzorgers zelf vinden vaak van niet. Iets meer dan de helft van de mantelzorgers die betrokken waren bij een keukentafelgesprek vond dat er geen aandacht was voor de hulp die zij geven. Ook komt hun ondersteuningsbehoefte vaak niet aan bod. Als er wel aandacht was voor mantelzorgers dan was ongeveer twee derde daar tevreden over [3].

\section{Hoe kunnen thuiszorgmedewerkers mantelzor- gers ondersteunen?}

Niet alleen gemeenten kunnen meer voor mantelzorgers doen, maar ook thuiszorgmedewerkers (zoals Wmo-hulp of wijkverpleegkundigen) kunnen een belangrijke rol spelen, bijvoorbeeld door te signaleren en te luisteren, en mantelzorgers goed te informeren over de mogelijkheden voor ondersteuning. Zo geven mantelzorgers bijvoorbeeld aan dat zij meer mogelijkheden willen om mee te beslissen over de zorg en dat beroepskrachten hen te weinig als deskundige zien. Ook vindt de helft dat thuiszorgmedewerkers onvoldoende oog voor hen hebben.

\section{Het bereik van mantelzorgondersteuning is be- perkt}

Vrijwel alle gemeenten bieden uiteenlopende vormen van mantelzorgondersteuning aan, zoals informatie, advies en respijtzorg [4]. Toch is er nog een aanzienlijke groep mantelzorgers die (meer) ondersteuning zou willen hebben. Een op de tien zou (meer of vaker) gebruik willen maken van respijtzorg en drie op de tien hebben behoefte aan informatie, advies, een cursus of lotgenotencontact [1]. Een belangrijke oorzaak van deze onvervulde behoefte is dat mantelzorgers niet goed op de hoogte zijn van het bestaan van ondersteunende voorzieningen of dat zij niet goed weten waar zij terecht kunnen voor ondersteuning. Gemeenten kunnen hen die informatie verstrekken. De meerderheid van de mantelzorgers gaf echter aan dat 'de gemeente' niet weet dat zij mantelzorger zijn [3]. Dit is lastig te begrijpen, omdat veel mantelzorgers betrokken zijn bij het keukentafelgesprek, maar ook heel jammer omdat er duidelijk aanwijzingen zijn dat gerichte ondersteuning van informele helpers overbelasting helpt te verminderen of zelfs kan voorkomen.

\section{Wat kunnen gemeenten en thuiszorgmedewer- kers doen?}

Concluderend blijkt dat zowel gemeenten als zorgmedewerkers meer kunnen doen voor hun mantelzorgers. Zelfs als mantelzorgers aanwezig zijn bij het keukentafelgesprek, komen zij vaak niet aan bod. Gemeenten zouden niet alleen cliënten, maar ook mantelzorgers serieuzer moeten nemen en er meer werk van kunnen maken hen op te sporen en te betrekken bij het gesprek. Zorgmedewerkers kunnen ook veel meer doen, bijvoorbeeld met onlangs ontwikkelde toolkits [5].

Gemeenten en zorgmedewerkers, heb oog voor de behoeften van mantelzorgers en toon waardering, ook als ze niet op de voorgrond treden [3]!

\section{Literatuur}

1. Klerk M de, Boer A de, Plaisier I, et al. Voor elkaar? Stand van de informele hulp in 2016. Den Haag: Sociaal en Cultureel Planbureau; 2017.

2. Bredewold F, Kampen T, Verplancke L, et al. Een mooie gedachte. Wat professionals denken over zelfredzaamheid en wat ze vervolgens (niet) doen. Amsterdam/Utrecht: Universiteit van Amsterdam/Universiteit voor Humanistiek; 2016.

3. Feijten P, Schellingerhout R, Klerk M de, et al. Zicht op de Wmo 2015. Ervaringen van melders, mantelzorgers en gespreksvoerders. Den Haag: Sociaal en Cultureel Planbureau; 2017.

4. Ham L van der, Draak M de, Mensink W, et al. De Wmo 2015 in praktijk. De lokale uitvoering van de Wet maatschappelijke ondersteuning. Den Haag: Sociaal en Cultureel Planbureau; 2018.

5. Movisie. Toolkit Samenwerken met mantelzorgers - zo werkt het. https://www.movisie.nl/publicatie/toolkitsamenwerken-mantelzorgers-zo-werkt. Geraadpleegd op 29 oktober 2019. 